\title{
JUURNAL.RU
}

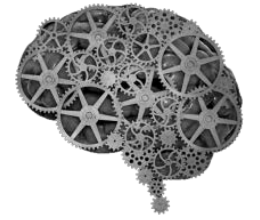

COMPANY GROUP "INTELLEKT"

Синькевич Г.П. Анапский филиал ФГБОУ ВО «Московский педагогический государственный университет» Анапа, Россия

doi: 10.18411/lj2016-6-3-10

\section{Инновационная деятельность как фактор развития готовности будущих специалистов социальной сферы}

В современных условиях рыночной экономики Россия идёт по пути инновационного развития во всех сферах жизни общества, особенно экономической и социальной. Предъявляя специфические требования к личности, к обществу в целом, современность рассматривается как эпоха инновационного развития, которая включает в себя целый ряд мер по качественному обновлению социальной сферы, на что указывает программа развития страны до 2020 года.

Исходя из этого, обществу нужны знания и умения, которые позволили бы эффективно участвовать в инновационных процессах, нужны специалисты, готовые к инновационной деятельности, имеющие необходимые личностные установки, качества и ценности.

Инновационные процессы сегодня в той или иной степени охватили практически все сферы общества: экономическую, политическую, духовную и, конечно, социальную. Социальная работа в настоящее время придает инновационный характер развития нашему обществу, помогает каждому человеку. Процесс развития общества идет через обновление и обусловливает создание предпосылок для формирования новых нетрадиционных компонентов в социальной сфере, инновационных способов социальной деятельности, а 
нововведения являются формой этого общественного развития. Методы, приёмы инновационной деятельности направлены на создание и материализацию нововведений в обществе, реализацию таких инициатив, которые вызывают качественные изменения в разных сферах социальной жизни, приводят к рациональному использованию материальных и других ресурсов в обществе.

Основная цель инновационной деятельности в социальной сфере - это решение социальных проблем современного общества, а сама деятельность в социальной работе обусловлена необходимостью поиска новых более эффективных и малозатратных способов решения социальных проблем населения. Можно выделить основные направления инновационной деятельности в социальной работе:

1) социальная активность, самодеятельность и самообслуживание широких слоев населения;

2) удовлетворение информационных потребностей и реализация прав граждан, используя информационные ресурсы;

3) индивидуализация социальных услуг, отход от массового производства;

4) организационные формы и технологии удовлетворения социальных потребностей общества.

Социальная деятельность - это та сфера, где требуются инновации, т.к. каждый раз это движение вперед, новые эффективные пути решения поставленных вопросов. Деятельность социальной работы направлена на позитивные изменения в различных сферах общества и должна обеспечить социальное благополучие и общее благосостояние. Во все сферы жизнедеятельности активно внедряются инновации, а именно:

- качество жизни населения;

- здравоохранение, материнство и детство;

- все виды и формы образования; 
- культура и досуг;

- социальная защита;

- право граждан на жильё;

- общественная безопасность;

- охрана окружающей среды;

- опека и попечительство в отношении детей, инвалидов, стариков и малоимущих граждан.

Формирование готовности к инновационной деятельности специалистов социальной сферы является одним из важных направлений. Значимость исследования данной проблемы является основой для развития важных профессиональных качеств. Для этого необходимо непрерывно работать над собой, над совершенствованием своих умений, знаний, развивать организаторские и коммуникативные способности и качества, которые позволят творчески, новаторски подойти к решению профессиональных проблем в условиях инновационного развития социальной сферы.

Если разработанные социальные инновации будут внедрены в перечисленные выше сферы жизнедеятельности, то, несомненно, это будет важным фактором экономического, социального и культурного прогресса всех современных обществ, это явится средством удовлетворения общественных потребностей и будет служить улучшению организации социальной работы, способствовать повышению ее эффективности и качества, статуса профессии в обществе, уровня его моральности.

Решение социальных проблем и улучшение их социального функционирования зависит от разработки, освоения социальных технологий и социальных программ, внедрения их в практику социальной работы с различными категориями клиентов. Важно отметить и то, что существенной особенностью инновационной деятельности специалиста по социальной работе 
является личностный подход и разработка социальных технологий, развивающих личность клиента.

Инновационный продукт является результатом инновационной деятельности специалиста по социальной работе, и его инновационные функции должны проявляться в творческом подходе к социальной деятельности: поиск новых технологий социального обслуживания, обобщение и внедрение передового опыта, умение использовать слабые и сильные стороны деятельности социальной организации.

Специалисту по социальной работе инновационная деятельность даёт возможность внедрять в практику социальные программы и технологии, проводить научно-исследовательские и проектные исследования в социальной сфере, что обеспечит успешное продвижение реформ и их позитивную результативность.

Поэтому молодым специалистам нового типа требуется социальнопсихологическая подготовка в условиях динамичных социально-экономических изменений, которые вынуждают искать новые пути к качественному изменению состояния высшего образования, которые обеспечивают подготовку специалистов к инновационной деятельности в социальной сфере, подготовку профессионалов, нацеленных в своей деятельности на решение социальных, экономических, экологических, политических и других проблем современного общества.

Для подготовки кадров новой формации, модернизации программ и технологий подготовки профессиональных специалистов инновационной России в ближайшие годы необходимо обеспечить комплексный подход к формированию инновационной системы и инвестиционной среды в целом. В социальной сфере государственная программа должна соответствовать требованиям к созданию инновационной среды, включая развитие человеческого капитала, формирование государственного спроса на инновационную продукцию, улучшение инвестиционного климата. 
В бюджетном послании Президента Российской Федерации от 13 июня 2013 г. «О бюджетной политике в 2014 - 2016 годах» В.В. Путин отмечает, что наметилась тенденция негативных изменений структуры бюджетных расходов регионов - падение объемов и доли расходов инвестиционного характера.

Поэтому именно сегодня все ранее поставленные цели не потеряли своей актуальности и должны быть достигнуты с учетом новых вызовов: квалифицированные специалисты, талантливые ученые, качественное образование и постоянное профессиональное обучение. В целях преемственности поколений в сфере научных исследований и технологических разработок большое внимание необходимо уделять их подготовке, следует стремиться к росту научного потенциала нашей страны, накоплению объектов интеллектуальной собственности. Необходимо уделить внимание образованию, повышению квалификации, улучшению здоровья граждан, формированию здорового образа жизни, созданию условий для повышения трудовой и творческой активности.

Сегодня обществу нужны люди, которые могут принимать ответственные решения в ситуации выбора, прогнозировать их возможные последствия, сотрудничать, развиваться в социальной, профессиональной и инновационной деятельности в социальной сфере. Это ориентация не столько на усвоение студентами знаний, умений и навыков, сколько на развитие личности, познавательных и созидательных способностей молодых людей. Очевидно, что система образования нуждается в модернизации, чтобы соответствовать реалиям жизни в глобальном и быстроменяющемся мире.

Идейные основы образовательного учреждения традиционного типа закладывались в первой половине прошлого века под влиянием потребностей индустриального общества.

В XXI веке модернизация и инновационное развитие - тот путь, который представит Россию конкурентным обществом. Пришло время специально закладывать в профессиональную подготовку личности социально- 
психологическую готовность к самосовершенствованию, саморазвитию, к переменам.

Для этого необходимо обладать такими важнейшими качествами личности, как: «инициативность, способность творчески мыслить и находить нестандартные решения, умение выбирать профессиональный путь, готовность обучаться в течение всей жизни», поэтому на рынке образовательных услуг, в условиях современной конкуренции, задача вуза - обеспечить выпуск инновационно-активных специалистов.

Из всего вышесказанного можно сделать вывод о том, что современной России нужны специалисты владеющие способностями к инновациям, творчеству, международному общению, трансляции знаний. Большое значение приобретает создание условий и возможности подготовки будущих профессионалов инновационной России, создание экспериментальной базы для подготовки специалистов, совершенствование содержания подготовки, развития личности профессионала. Нужно совершенствовать и оздоравливать образовательную и научно-техническую систему вузов, связанную с требованиями построения государства инновационного типа. В этих условиях одной из главных задач высшего профессионального образования является подготовка специалистов, способных к инновационной деятельности. 


\section{Список используемых источников информации}

1. Березанская Н. Б. Инновации в образовании или инновационное образование? // Инновации , 2008. - № 10 (120). - С. 99 - 102.

2. Бюджетное послание Президента РФ В.В. Путина от 13 июня 2013 г. «О бюджетной политике в 2014 - 2016 годах».

3. Витун С.Е. Инновационное образование в высшей школе и повышение его качества // Материалы международной научно-практической конференции «Подготовка научных кадров высшей квалификации в условиях инновационного развития общества» / Под ред. И.В. Войтова. - Минск: ГУ «БелИСА», 2009. - 288 с.

4. Волченкова, Т.В. Формирование у педагогов готовности к инновационной педагогической деятельности/Т.В.Волченкова//Ежемесячный теоретический и научно-методический журнал «Среднее профессиональное образование». - 2009. - № 12. - С. 2 - 4 .

5. Лю Чуань-Шень, Сяу Су Источник энергии современных вузов: качество, самобытность, инновации // Высшее образование сегодня. 2007. - № 12. C. $18-21$.

6. Нейхц Н. П., Решетников В. А. Традиция и инновация в социальной работе // Вестник Иркутского университета. Специальный выпуск. Материалы ежегодной научно-теоретической конференции молодых ученых. Иркутск, 2000.

7. Подготовка научных кадров высшей квалификации в условиях инновационного развития общества»/ Подред. И.В. Войтова. - Минск: ГУ «БелИСА», 2009. - 288 с.

8. Технология социальной работы: Учебник / Под общ. ред. Проф. Е.И. Холостовой. - М.:ИНФРА - М. - 2003. - 400с.

9. Эмиров Н. Д.Проблемы современной экономики, № 4 (36), 2010. 